\title{
Assessment of Groundwater Salinity in Aloha Pliocene Aquifer of Marbella (Málaga)
}

\author{
S. Espinosa Martinez ${ }^{1, *}$, M. A. Díaz ${ }^{1}$, J. Antonaya Avi ${ }^{2}$, Y G. Calero Diaz \\ ${ }^{1}$ Cetaqua Andalucía, Spain \\ ${ }^{2}$ Hidralia Integral Management of Water of Andalusia S.A., Spain
}

Copyright $(2019$ by authors, all rights reserved. Authors agree that this article remains permanently open access under the terms of the Creative Commons Attribution License 4.0 International License

\begin{abstract}
In order to study the origin of the salinity and the salinization mechanisms that operate in the Pliocene Aloha Aquifer, hydrochemical and isotopic environmental techniques have been used, due to their known effectiveness and usefulness in the identification of water-rock interaction processes, location of recharge zones and its origin. Analyzing major ions, trace elements, ionic ratios and isotopic ratios of the elements of the water molecule, stable isotopes $\left(\delta^{18} \mathrm{O}\right.$ and $\left.\delta^{2} \mathrm{H}\right)$ and $\delta^{18} \mathrm{O}$ and $\delta^{34} \mathrm{~S}$ of sulphate. Previous hydrochemical studies of the Pliocene Aloha Aquifer indicate high concentrations of $\mathrm{Cl}^{-}$ and $\mathrm{Na}^{+}$as well as $\mathrm{HCO}_{3}, \mathrm{SO}_{4}$ and $\mathrm{Ca}$ that should be indicated the interaction with waters of highersalinity, but also with rocks (longer residence time in the aquifer). Therefore, as a starting hypothesis, two possible origins of the high salinity are considered: mixture with seawater or connate waters stored in Pliocene formations. Finally, the study confirmed that the salinity of the Aloha Aquifer is of a localcharacteristic and not due to seawater intrusion.
\end{abstract}

Keywords Hydrogeochemistry, Salinity, Ionic Ratios, Isotopes, Coastal Aquifer

\section{Introduction}

Salinization of coastal aquifers is a global problem that concerns concessionaires, operators and exploiters as well as the scientific community, as it affects the quality of the water resource due to the processes of saline intrusion during periods of drought. This problem is even more pronounced in vacation areas, such as Marbella, where the population can be doubled or even tripled in summer, intensifying pumpings from wells, inducing the penetration of the seawater wedge. The mechanisms of salinization of aquifers may have anthropogenic origin (pumping, irrigation returns or use of urban and industrial waste water) or natural origin (interaction with rocks or in the case of congenital water) (Custodio, 1981; Custodio \& Llamas, 1983). Therefore, to adapt aquifer management plans to allow the sustainable use of water resources, it is necessary to determine the origin of the aquifer's salinity in order to apply the appropriate corrective actions.

In 1995 one of the worst droughts of recent times occurred in this area, where the water table levels fall $44 \mathrm{~m}$ below sea level, reaching electrical conductivity (EC) values around $10 \mathrm{mS} / \mathrm{cm}$ in the deeper wells. The shallower wells were not affected. After that drought, the chemical quality of the groundwater improved, maintaining the EC at $0.7-0.9 \mathrm{mS} / \mathrm{cm}$ until 2003. From that year, the trend was moderately increasing until it stabilized at average values of $1.1 \mathrm{mS} / \mathrm{cm}$.

The aim of this study is to determine the origin of salinity and the hydrogeological processes responsible for the salinization of Aloha Aquifer by means the application of advanced hydrogeochemical and isotopic techniques. As a starting hypothesis, two possible origins of high salinity are considered: mixing with seawater or presence of connate waters stored in Pliocene formations.

\section{Study Area}

The studied area is located on the west cost of Málaga between Marbella and San Pedro de Alcántara urban centers. The considered area has approximately $12 \mathrm{~km}^{2}$ and it is delimited to the north by the mountain range from the Sierras Bermeja (1508 m) and Blanca (1270 m) (Figure 1). 


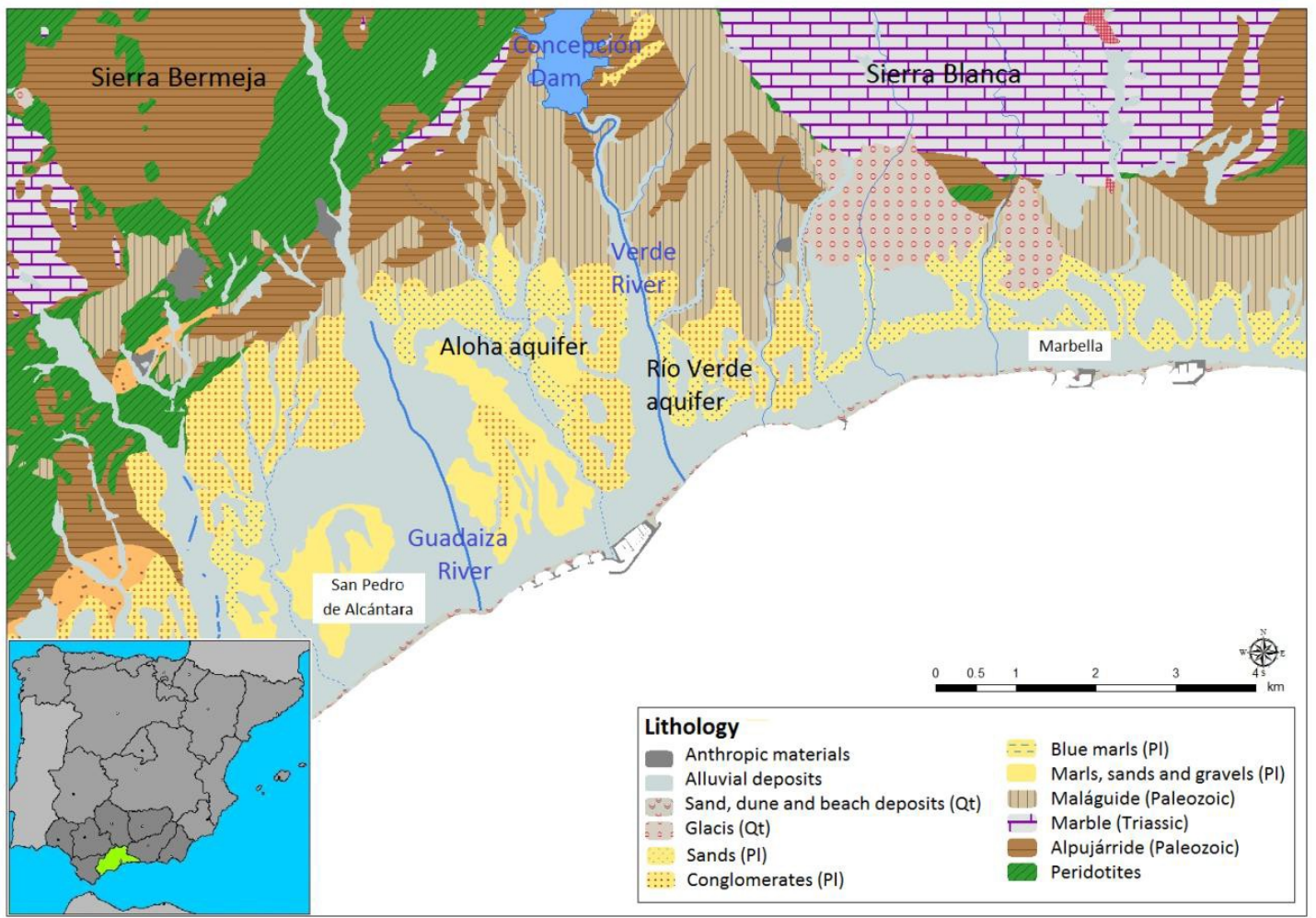

Figure 1. Study area location and hydrogeological settings

These mountains constitute the headstream of Verde River, east boundary of the study area, Benabolá Stream and Guadaiza River to the west (Figure 1). The southern limit is the coastline of Mediterranean Sea. The topographic level of this area does not exceed $200 \mathrm{~m}$ altitude, contrasting with the high mountainous reliefs previously mentioned (Lupiani, 2007). The average rainfall in the area is $700 \mathrm{~mm} / \mathrm{a}$ with temperatures of $13^{\circ} \mathrm{C}$ in winter and $26^{\circ} \mathrm{C}$ in summer (Argamasilla et al., 2017). The surrounding urban centers are Marbella and San Pedro de Alcantara with 104 thousand and 35 thousand inhabitants respectively (INE, 2016).

Two sedimentary aquifers are distinguished, one the lower of Pliocene age (Aloha Aquifer) and a higher one of the Quaternary age (Río Verde Aquifer), which rest discordantly on the Paleozoic impermeable substrate, which includes the Alpujárride and Málaguide formations (Figure 1). The Aloha Aquifer, formed by conglomerates, sands and sandy loams, tilts slightly towards the coast $\left(5^{\circ}\right.$ to $10^{\circ}$ ) where it reaches the biggest thicknesses $(150 \mathrm{~m})$, constituting a multilayer aquifer with permeable levels of $20 \mathrm{~cm}$ to $10 \mathrm{~m}$ thick with frequent intercalations of low permeable levels. In the Río Verde Aquifer, discordant over the previous ones, fluvial deposits formed by boulders, gravels and sands can be distinguished with a sparse silt-clay matrix (Lupiani, 2007). The recharge of these aquifers comes from the precipitation and the infiltration of the superficial runoff in the basin. The discharges take place underground to the sea and by pumping in the groundwater catchment points.

\section{Methods}

For evaluation the origin of salinity, hydrogeochemical and isotopic techniques have been applied to characterize groundwater chemically by means of complete elemental chemistry analysis, ionic ratios analysis, stable isotopes $\left(\delta^{18} \mathrm{O}\right.$ y $\left.\delta^{2} \mathrm{H}\right)$ of the water molecule and sulphate isotopes $\left(\delta^{18} \mathrm{O}_{\mathrm{SO}_{4}}\right.$ y $\left.\delta^{34} \mathrm{~S}_{\mathrm{SO}_{4}}\right)$ analysis, combined with the available information of regional structural and hydrogeological nature.

Five wells managed by Hidralia have been sampled, four of them pump water from the Pliocene Aloha Aquifer and the last one from the Verde River Alluvial Aquifer (Figure 2). To complete the study, data published by Argamasilla et al., 2017 (Marbella-Estepona aquifers) had been used to complement the study, where 6 water groups are differentiated for their chemical characteristics (group A: Estepona Aquifer, group B: San Pedro de Alcántara, group C: alluvial aquifers, group D: Aloha Aquifer, group E: Señorío Aquifer and group F: Real-Cabo Pino Aquifer). The data analysis of seawater and surface water from the Verde River have also been used in this work.

Not all the wells are equipped and consequently the samples extracted from these may have less reliability in the results. Therefore, two sampling campaigns have been carried out (December 2016 and January 2017) to observe the variability of the samples. 


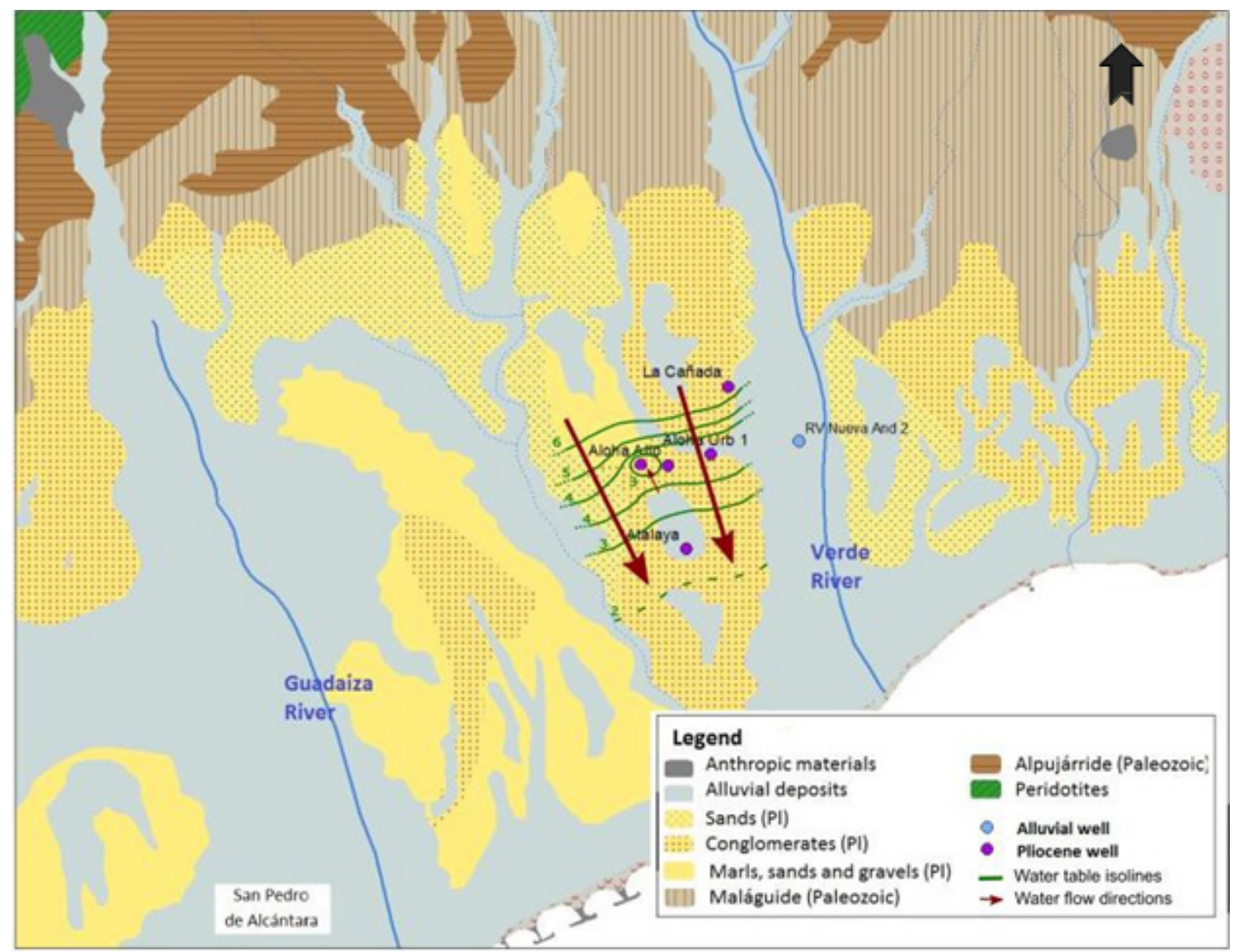

Figure 2. Sampled wells location and water flow direction of Aloha Pliocene Aquifer

\section{Results and Discussion}

The groundwater of these aquifers is calcium-magnesium bicarbonate (Figure 3). As expected, it can be observed that the samples from the Río Verde Aquifer are less mineralized since they come from the direct infiltration of the rain and the flow through the Verde River resulting from the discharge of $\mathrm{La}$ Concepción dam (Figure 1). The Pliocene Aloha Aquifer groundwaters have higher magnesium concentration (Table 1), possibly due to the influence of the bedside peridotitic massifs (Argamasilla and Andreo, 2013). Piper diagram shows that the waters of the Pliocene aquifers are closer to the surface water (Verde River) and the groundwater sample of the Río Verde Aquifer (RVerde-NA 2) than the sample of seawater.

In terms of ionic ratios, values corresponding to continental waters are generally observed (Figure 3). For $\mathrm{rNa}^{+} / \mathrm{rCl}^{-}$the typical value for seawater is 0.88 and very variable for freshwater (Custodio and Llamas, 1983), in this case the values are lower. The ratio $\mathrm{rNa}^{+} / \mathrm{rK}^{+}$provides information on the continental or marine origin of $\mathrm{K}^{+}$, seawater ranges between 40-50 (Custodio and Llamas, 1983), and continental water values range between 3 and 250 , so its marine origin cannot be verified. The $\mathrm{rMg}^{2+} / \mathrm{rCa}^{2+}$ are 5 for marine water, so the marine influence also cannot be verified by this ionic relationship because all the values are lower. The $\mathrm{rSO}_{4} / \mathrm{r}$ Clcharacteristic for continental waters oscillates between $0.2-0.4$ being 0.11 for marine values and none of the samples is less than 0.2 in this relation. For the $\mathrm{rCl}^{-} / \mathrm{rHCO}^{-}$, the sea water values oscillate between 20 and 50 (Custodio and Llamas, 1983), with a clear predominance of $\mathrm{Cl}$ against bicarbonate, however the continental water values for this relation oscillate between 0,1 and 5, range in which the sampled points are found. Finally, the $\mathrm{rCl}^{-} / \mathrm{rBr}^{-}$values of the Mediterranean Sea are around $655 \pm 25$, the aquifer values (Table 2) are lower or much higher than this value indicating recharge in coastal urban areas (marine aerosol plus pollution) or mix with urban wastewater, respectively (Custodio and Alcalá, 2004). 

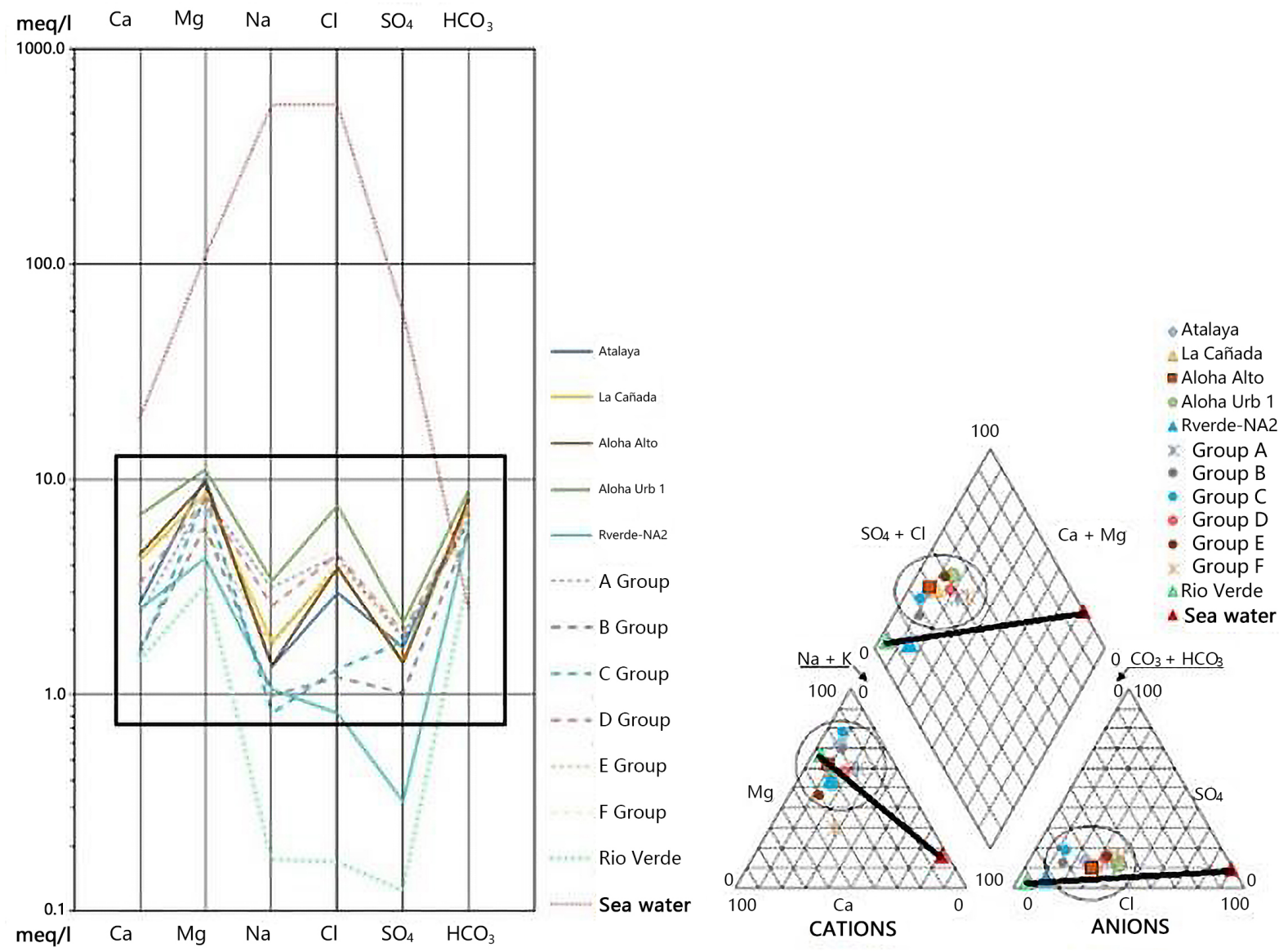

Figure 3. Schoeller-Berkaloff, Piper diagrams of the groundwater control points 
Table 1. Average results of chemical analyses

\begin{tabular}{|c|c|c|c|c|c|c|c|c|c|c|c|c|c|c|}
\hline OBS. POINT & $\begin{array}{c}\mathrm{CE} \\
(\mu \mathrm{S} / \mathrm{cm})\end{array}$ & $\begin{array}{c}\mathrm{T} \\
\left({ }^{\circ} \mathrm{C}\right)\end{array}$ & $\underset{(\mathrm{mg} / \mathrm{l})}{\mathrm{pH}}$ & $\begin{array}{c}\text { TOC } \\
(\mathrm{mg} / \mathrm{l})\end{array}$ & $\begin{array}{c}\mathrm{Cl}^{-} \\
(\mathrm{mg} / \mathrm{l})\end{array}$ & $\begin{array}{c}\mathrm{Br}^{-} \\
(\mathrm{mg} / \mathrm{l})\end{array}$ & $\begin{array}{c}\mathrm{NO}_{3} \\
(\mathrm{mg} / \mathrm{l})\end{array}$ & $\begin{array}{c}\mathrm{SO} 4 \\
(\mathrm{mg} / \mathrm{l})\end{array}$ & $\begin{array}{c}(\mathrm{TAC}) \mathrm{HCO}- \\
(\mathrm{mg} / \mathrm{l})\end{array}$ & $\begin{array}{c}\mathrm{Na} \\
(\mathrm{mg} / \mathrm{l})\end{array}$ & $\underset{(\mathrm{mg} / \mathrm{l})}{\mathrm{K}}$ & $\begin{array}{c}\mathrm{Mg} \\
(\mathrm{mg} / \mathrm{l})\end{array}$ & $\begin{array}{c}\mathrm{Ca} \\
(\mathrm{mg} / \mathrm{l})\end{array}$ & $\underset{(\mathrm{mg} / \mathrm{l})}{\mathrm{Sr}}$ \\
\hline Atalaya & 1116 & 17,4 & 7,5 & 0,5 & 106,4 & 0,6 & 7,8 & 79,4 & 460,0 & 31,2 & 1,6 & 123,7 & 53,5 & 0,4 \\
\hline La Cañada & 1376 & 18,2 & 7,4 & 0,7 & 137,1 & 0,4 & 8,0 & 70,2 & 457,5 & 40,8 & 2,5 & 104,2 & 84,1 & 0,5 \\
\hline Aloha Alto & 1641 & 16,9 & 7,3 & 1,0 & 139,6 & 0,7 & 9,4 & 68,1 & 503,5 & 31,6 & 1,8 & 117,7 & 90,4 & 0,4 \\
\hline Los Naranjos & 1112 & 19,3 & 8,3 & 2,6 & 24,2 & 0,0 & 0,5 & 21,6 & 115,5 & 9,9 & 5,6 & 12,8 & 31,9 & 0,2 \\
\hline Aloha Urb 1 & 1321 & 20,1 & 7,3 & 2,1 & 270,1 & 0,7 & 13,8 & 104,3 & 549,0 & 78,2 & 2,2 & 134,2 & 137,3 & 0,5 \\
\hline RV-Nueva And 2 & 771 & 15,5 & 7,7 & 0,3 & 31,8 & 0,4 & 1,7 & 18,8 & 338,8 & 26,4 & 1,7 & 50,8 & 48,7 & 0,3 \\
\hline
\end{tabular}

Table 2. Ionic ratios of the groundwater control points

\begin{tabular}{|c|c|c|c|c|c|c|}
\hline & $\mathrm{rNa} / \mathrm{rCl}$ & $\mathbf{r N a} / \mathbf{r K}$ & $\mathrm{rMg} / \mathrm{rCa}$ & $\mathrm{rSO}_{4} / \mathrm{rCl}$ & $\mathrm{rCl} / \mathrm{rHCO3}$ & $\mathrm{rCl} / \mathrm{rBr}$ \\
\hline Atalaya & 0,46 & 33,10 & 3,86 & 0,56 & 0,40 & 399,12 \\
\hline La Cañada & 0,47 & 28,23 & 2,12 & 0,38 & 0,51 & 1647,14 \\
\hline Aloha Alto & 0,35 & 30,74 & 2,15 & 0,36 & 0,48 & 486,93 \\
\hline Aloha Urb 1 & 0,45 & 61,54 & 1,62 & 0,29 & 0,83 & 868,45 \\
\hline RVerde-NA 2 & 0,76 & 52,26 & 0,71 & 0,41 & 0,81 & 237,73 \\
\hline
\end{tabular}



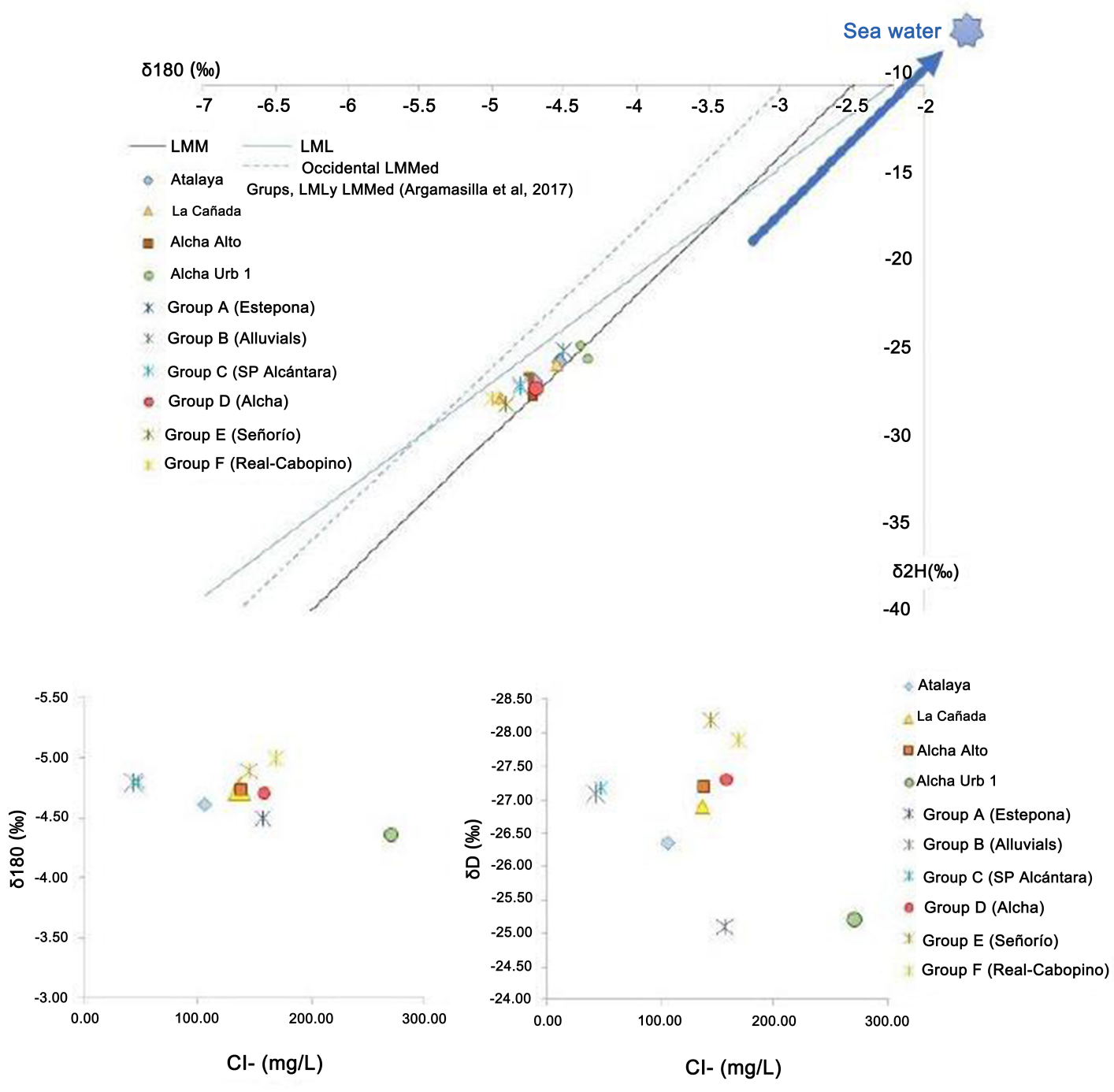

Figure 4. Stable isotope analysis of the water molecule of the groundwater Pliocene Aloha aquifer (top) and ratio $\delta^{18} \mathrm{O}$ and $\delta^{2} \mathrm{H}$ vs $\delta^{18} \mathrm{O}-\mathrm{Cl}{ }^{-}($botto m)

The values of $\delta^{18} \mathrm{O}$ and $\delta^{2} \mathrm{H}$ range between -4.37 and $-5 \%$ and -25.20 and $-28.20 \%$, respectively (Figure 4), with an average deuterium excess of $10.84 \%$ so it could be an area influenced by rains from Atlantic fronts (Atlantic d: $10 \%$; Cruz-San Julián et al., 1992). Likewise, the mean values of $\delta^{18} \mathrm{O}$ and $\delta^{2} \mathrm{H}$ of the rains recorded at the Gibraltar station of the GNIP (west of the study area) are -4.21 and $-22.5 \%\left(\delta^{18} \mathrm{O}\right.$ and $\delta^{2} \mathrm{H}$, respectively) and -4.26 and $-27.5 \%\left(\delta^{18} \mathrm{O}\right.$ and $\delta^{2} \mathrm{H}$, respectively) at the Almería airport station (east of the study area) (GNIP, 2017), so it could be said that the Pliocene Aloha Aquifer waters have a strong influence of recharge water generated by precipitation events.

The values of $\delta^{18} \mathrm{O}$ and $\delta^{2} \mathrm{H}$ for seawater are close to $0 \%$, considering that the isotopic mark of the Mediterranean Sea is slightly enriched with respect to $\mathrm{V}$-SMOW if there were marine influence in the Aloha Aquifer, values of $\delta^{18} \mathrm{O}$ would be less negative. On the other hand, it is known that the quality of San Pedro de Alcántara Aquifer is very good to use as drinking water and there is no evidence of having suffered historically contamination by marine intrusion (internal HIDRALIA reports). Group C is a good reference to compare the isotopic values of this aquifer with those sampled in the Pliocene Aloha Aquifer, resulting to be very similar.

The samples of Aloha Urb. 1 well are a bit heavier than the others and with a higher relation $\delta^{18} \mathrm{O}-\mathrm{Cl}^{-}$, which can be explained by a possible saltwater upwelling phenomenon caused by an intense pumping.

It is observed by means the sulphate isotopes, that the Pliocene Aloha Aquifer values are far from the normal values of modern oceanic sulphate, setting on the area of fertilizers and atmospheric sulphate (Figure 5 and 6 ).

To verify the nature of the sulphate in Pliocene groundwater, the values in the chart $\delta^{18} \mathrm{OsO}_{4}$ vs $\delta^{18} \mathrm{OH} 20$ (Figure 5) have been represented by differentiating the sulphate fields formed by oxidation of atmospheric $\mathrm{SO}_{2}$ from those formed by oxidation of sulfides. In this case, they appear in the oxidation field of atmospheric $\mathrm{SO}_{2}$ possibly due to air pollution. 


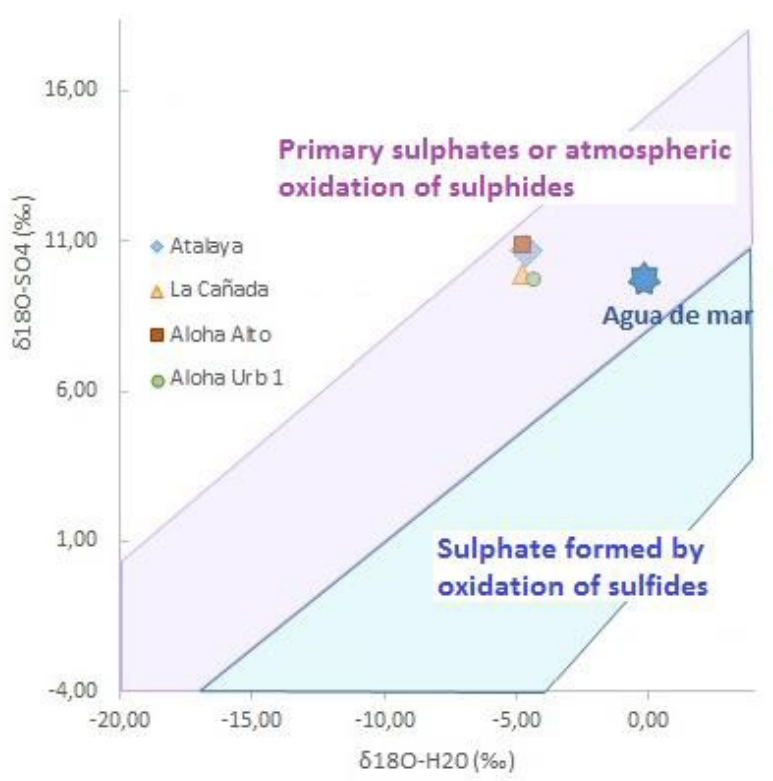

Figure 5. Sulphate isotopes of the Pliocene Aloha Aquifer on the chart of "Field of sulphates formed by oxidation of sulfides", according Van Stempvoort and Krouse (1994)
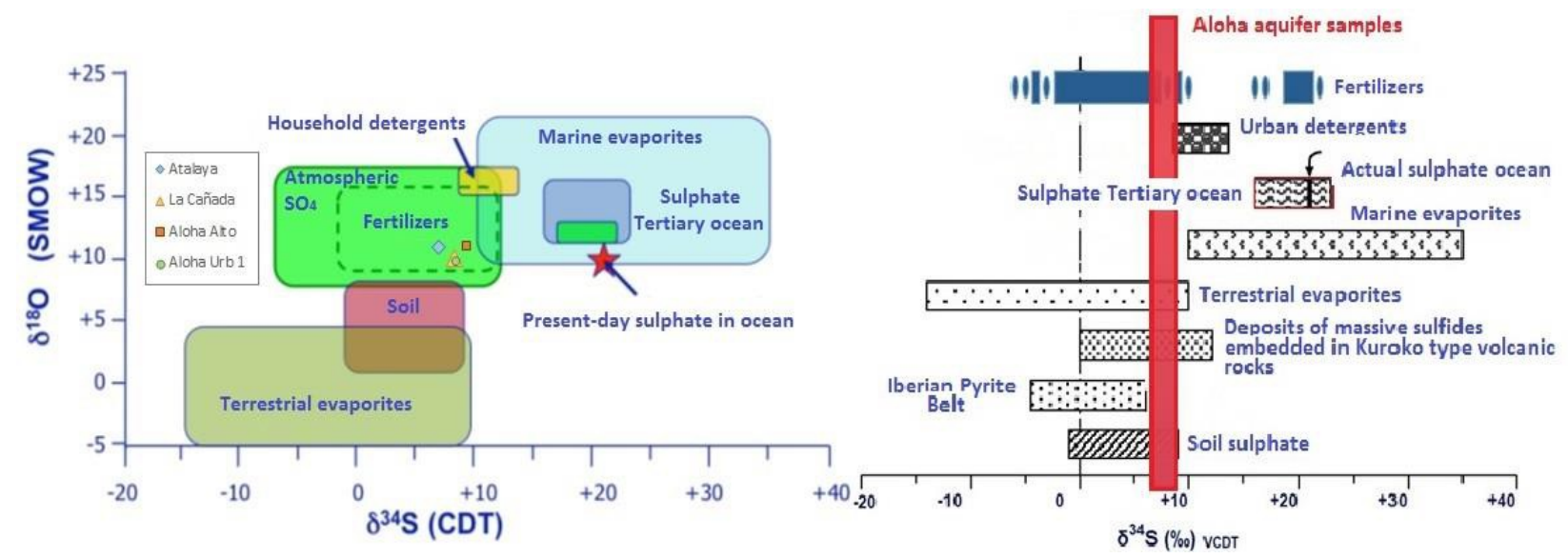

Figure 6. Sulphate isotopes of the Pliocene Aloha Aquifer on the chart of "variations in the $\delta^{34} \mathrm{~S}$ and the $\delta^{18} \mathrm{O}$ of sulphate in different natural materials and anthropic compounds" according Vitoria et al. (2004)

\section{Conclusions}

Both the Pliocene Aloha and the Río Verde aquifers have calcium-magnesium bicarbonate characteristics, with the possible influence of the peridotitic massifs at the bedside. There is a significant isotopic compositional difference of the Aloha Aquifer with respect to the sea water, observing local characteristics like aquifers that have not been contaminated by the sea water intrusion, such as San Pedro de Alcántara.

It is discarded that currently the aquifer is subject to contamination by saline intrusion. Likewise, its groundwater has a high renewal rate, so the hypothesis of the presence of connate waters is also discarded.

However, a third hypothesis about the significantly diluted residual effect of the marine intrusion occurred as a result of the great drought of 1995 . This hypothesis could not be validated because there are no chemistry registers before the drought, hence the EC that the aquifer had before 1995 is not known.

This study shows the good management carried out by HIDRALIA in the area that is already an aquifer susceptible to salinization and there is no evidence of intrusion at present.

\section{Acknowledgements}

This research project is part of the development of the project "Recharging managed Aloha Aquifer to maximize the use of surplus water resources (Marbella, Malaga)" funded by HIDRALIA Integral Management of Water of 


\section{REFERECES}

[1] Alcalá, F. J. and Custodio, E. (2004). La relación $\mathrm{Cl} / \mathrm{Br}$ como indicador del origen de la salinidad en algunos acuíferos de España y Portugal. XXXIII CIAH-ALSUHD. Zacatecas (México). ISBN: 970-32-179.

[2] Argamasilla, M. and Andreo, B. (2013). Caracterización Hidrogeoquímica preliminar de los acuíferos costeros de Marbella - Estepona. X Simposio de Hidrogeología. AEH. ISBN: 978-84-7840-914-3.

[3] Argamasilla, M., Barberá, J. A. and ndreo, B. (2017). Factors controlling groundwater salinization and hydrogeochemical processes in coastal aquifers from southern Spain. Science of the Total Environment. 580. 50-68. 10.1016/j.scitotenv 2016.11.173.

[4] Cruz-Sanjulián, J., Araguas, L., Rozanski, K., Benavente, J., Cardenal, F. J., Hidalgo, M. C., García-López, S., Martínez-Garrido, J.C., Moral, F. and Olías, M. (1992). Sources of precipitation over South-Eastern Spain and groundwater recharge. An isotopic study. Tellus, 44B, 226-236.

[5] Custodio Gimena, E. 1981. Evaluación y causas de la contaminación por invasión de agua marina en los acuíferos de la costa peninsular y en las áreas insulares. Jornadas Sobre Análisis y Evolución de la Contaminación de las Aguas Subterráneas en España. CIHS.

[6] Custodio E. and M. R. Llamas (1983). Hidrología Subterránea. Omega (1, 2 Vol.) 2359 pp. GNIP (2017). Global Network of Isotopes in Precipitation. The GNIP Database.

[7] (INE, 2016). Instituto de Estádistica y Cartografía de Andalucía (SIMA, 2016) (online search).http://www.junta deandalucia.es/institutodeestadisticaycartografia/sima/nucle os.htm

[8] Lupiani, E. (2007). Marbella - Estepona (M.A.S. 060.040). Atlas Hidrogeológico de la Provincia de Málaga. Diputación de Málaga - IGME. Tomo II, 155-160.

[9] Van Stempvoort D. R., Reardon, P. and Fritz E.J. (1990) Fractionation of sulfur and oxygen is otopes in sulfate by soil sorption. Geochimica et Cosmochimica Acta, Vol. 54, p2817-2826.

[10] Vitoria, L, Otero, O, Soler, A. and Canals, A. (2004) Fertilizer Characterization: Isotopic Data (N, S, O, C and Sr). Environmental Science \& Technology, 38, 3254-3262. 